\title{
EVALUATION OF NEW HYPOTHETICAL CONCEPT (LHSIR) FOR DIE PROFILE DESIGN FOR HYDROSTATIC EXTRUSION OF Al/Mg COMPOUND
}

\author{
Muhsin J. Jweeg ${ }^{1}$, Moneer H. Tolephih Al-Saady ${ }^{2}$, Abdullah Dhayea Assi ${ }^{3}$ \\ ${ }^{1}$ Prof., College of Engineering, AL-Nahrain University/ Baghdad, Iraq \\ ${ }^{2}$ Assistant Prof., the Technical College / Baghdad, Iraq \\ ${ }^{3}$ Lecturer, Institute of Technology / Baghdad, Iraq \\ E-mail: monerht@yahoo.com \\ (Received: 22/4/2012; Accepted: 25/12/2012)
}

\begin{abstract}
This paper presents, for the first time, a new developed concept for design of Die pass profile used in hydrostatic-extrusion of $\mathrm{Al} / \mathrm{Mg}$ compound. The new design criteria proposes a "Linearity" of the Homogeneous Successive Strain Increment Ratios (LHSIR) of the deformed material, instead of the "Constancy" concept (CHSIR) found in literature, as the tool base to generate the profile. The developed profiles were evaluated numerically to assess their relative pressure ratios as the main parameter for performance checking adopting the well-known Upper Bound Approach (UBA). A further developed aspect for the velocity field proposition is successfully made to carry out the necessary tedious computations. 12 different samples of commercial tool steel were CNCmanufactured, heat treated and tested to $\mathrm{Al} / \mathrm{Mg}$ compound, from lead alloy, for sake of comparison and validity assessment. The major conclusion comes out of this work claims that a small variance in the classical constancy criteria of the Die design is very sensitive to change the expected levels of the relative pressure ratios of the extrusion process.
\end{abstract}

Keywords: hydrostatic -extrusion, Die profile design, pressure ratio, Upper bound approach, Velocity field.

\section{$\underline{\text { Notations }}$}
A Billet cross-section area.
$\mathbf{R} \quad$ Die profile ordinates.
c Arbitrary constant
S Slab circumference.
Do Container inner surface diameter.
t Time.
h $\quad$ Forming thickness.
$\mathbf{u}, \mathbf{v} \quad$ Point-wise displacement.
$\mathbf{i}, \mathbf{j} \quad$ Integers, coordinates (x, y, z).
$\dot{\omega} \quad$ Deformation power per volume.
k Yield shear stress
$\mathbf{x}, \mathbf{y}, \mathbf{z}$ 3-Dimensional coordinates. 


\begin{tabular}{llll}
\hline $\mathbf{l}_{\mathbf{0}}$ & Pass geometry length. & $\boldsymbol{\sigma}_{\mathbf{0}}$ & Billet flow stress. \\
$\mathbf{m}$ & Friction coefficient. & $\boldsymbol{\alpha}$ & Die profile slop. \\
$\mathbf{m}_{\mathbf{0}}, \mathbf{S}_{\mathbf{0}}$ & Die design parameters. & $\boldsymbol{\varepsilon}_{\mathbf{H}}$ & Homogeneous strain. \\
$\mathbf{P}$ & Ram pressure. & $\eta_{\mathbf{P}}$ & Relative extrusion pressure.
\end{tabular}

Other notations are located at their correspond places.

\section{1- INTRODUCTION}

The huge evolution in production technology, nowadays, shows great demands and interest to develop and improve the main operation parameters in metal forming processes that satisfy high level of performance and inexpensively ${ }^{(1)}$. The industrial production of metallic $\mathrm{Al} / \mathrm{Mg}$ compound by backward extrusion performs one of important issues in this trend $^{(2)}$.

The basic core of such process consternates on the pass geometry function of the Die. The shape and the mathematical formality of the profile specify strongly the overall efficiency and productivity of the system. This matter is actively concerned with the design stage of the Die, whereas afterwards and before manufacturing, the analysis and verification stage of the billet plastic behavior comes next. The predicted relative pressure (and hence the rated capacity of the machine) stands as the major goal to be tolerated using relevant theoretical techniques such as slip-line field theory, viscoplasticity theory, equivalent strain method, classical slab method and UBA ${ }^{(3,4,5)}$, or adopting the numerical approaches of finiteelement method ${ }^{(6,7)}$. The design criteria of a Die profile takes two different aspects in application. The first aspect employs the profile shape arbitrary selected without apparent theory base in design. Most of these profiles are commercially manufactured and take the shapes of Flat, Taper, Cone, Elliptical, Cosine curves and other proposed geometry of truncated surface of revolution. The second aspect provides the profile curves to maintain typical features of plasticity deformation in the forming region between the container and/or die inner surface and the Die pass surface. The design theoretical base of these Dies propose particular relationship between the homogeneous plastic strain and the space position under consideration. Including the non-homogeneous strain effects makes the criteria very complicated and mathematically hard to be accomplished. In specific words, the abbreviations (HRS) and (MSR) are often used to distinguish between each other, but on the same theory spirit of the design criteria.

The first one focuses on the Homogeneous Relative Strain value at certain location to the corresponding value at successive or neighbor position, whereas the second one implies the Mean of homogeneous Strain Rate at arbitrary location of the forming domain. All of 


\section{EVALUATION OF NEW HYPOTHETICAL CONCEPT (LHSIR) FOR DIE PROFILE DESIGN FOR HYDROSTATIC EXTRUSION OF Al/Mg COMPOUND}

these criteria proposed the "Constancy" of the strain increment ratios or the mean strain rate all around the forming region, therefore the terms (CHRS, CMSR) become the corresponding notations for this special criteria since when Valdyanathan \& Blazynski ${ }^{(8)}$, and later Blazynski T.Z. (9) had conducted their work and made numerical and experimental comparison with the work of Chen and Ling ${ }^{(10)}$ who adopted commercial Die profiles. Samancto ${ }^{(11)}$ had studied "cosine" profile performance and applied the UBA for results

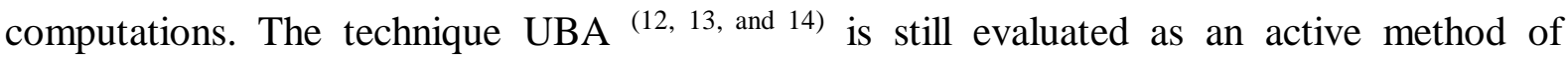
solution for majority of metal forming processes. It implies the calculation of the expected powers of deformation in the material (internal power), on the frictional surface of the container and Die (friction power) and at the artificial shear lines of velocity discontinuity of a particle (shear power), and then equating all with the external necessary power imposed by the ram (external power), from which the relative pressure of the process comes out as the main output parameter of these computations.

The mathematical foundation of the UBA is based upon two main concepts: one of which implies the well-known Von-Mises constitutive relations of the strain rate with its correspondent stresses, and another one which describes the proposed point-wise velocity vector of a particle within the zones of deformation. Much of history of UBA can be found in many textbooks of plasticity. Vaidyanathan \& Blazynski applied this approach on Diees designed according to CHRS and CMSR concepts. The same technique was utilized later by several authors who made experimental comparison of the relative pressure. Recently, the references ${ }^{(15,16)}$ are eventually classified within the same trend of researches. The numerical analysis, in these works, covered the effects of geometrical and mechanical parameters on the value of the relative pressure (those like the Die length, die diameter and the friction coefficient).

The present work tries to make new changes on the design criteria statements, starting with the inclusion of "linearity" concept in replacement of the classical one of "constancy". The new developed pass geometry profiles will be based upon the new Linearity of Homogeneous successive Strain Increment Ratios (LHSIR) concept formulized in the present paper. The aim is to investigate and assess its operational performance as compared with those of CHRS concepts. In order to utilize the UBA, the present paper also propose useful, rather simple formulae of the point-wise velocity vector as related with position, from which the overall powers of deformation, friction and shear would be formulized and quantified numerically by proper single and double integration procedures.

The complete formulization, of this technique, is found relatively tedious and lengthily, a matter which makes the re-proceeding with another propose concept of Linearity 
of the Mean Homogeneous Strain Rate (LMHSR) would be preferred to be accomplished later for work size reservation. Moreover, one may think consequently in creation of high order concepts, like those of "parabolic, cubic and others" variation of the strain increment ratios or the mean strain rates. All which will take much of present theoretical aspects, as the tool base of developments in further next coming works.

\section{2- THEORETICAL ANALYSIS}

The first two Figs. (1a, 1b), given herein, illustrate schematically the Die-die system for a typical hydrostatic extrusion of $\mathrm{Al} / \mathrm{Mg}$ compound using a commercial flat profile for the Die (Fig. (1a)) and another profile of typical curve (Fig. (1b)), both with necessary notations.

It is evident that the deformed material thickness $\mathrm{h}(\mathrm{x})$, as relates with position along the Die stem, and the Die profile ordinate $\mathrm{R}(\mathrm{x})$, measured from the centre line are correlated directly by:

$$
\mathrm{R}(\mathrm{x})=\frac{\mathrm{D}_{0}}{2}-\mathrm{h}(\mathrm{x})
$$

Where $\mathrm{D}_{0}$ denotes the container inner surface diameter. The present objective is to explore $\mathrm{R}(\mathrm{x})$ mathematically for design and manufacturing purposes, and that can be achieved from assessing of the admissible formality of $\mathrm{h}(\mathrm{x})$ as should be done next.

\section{The Generalized Homogeneous Strain Increment d $\varepsilon_{\mathrm{h}}$ :}

Referring to Levy-Mises stress-strain equations in 3-dimensional coordinate system (12), which state that:

$$
\begin{aligned}
& \dot{\varepsilon}_{\mathrm{x}}=\mu \mathrm{S}_{\mathrm{x}} \quad, \quad \dot{\varepsilon}_{\mathrm{y}}=\mu \mathrm{S}_{\mathrm{y}} \quad, \quad \dot{\varepsilon}_{\mathrm{z}}=\mu \mathrm{S}_{\mathrm{z}} \\
& \dot{\varepsilon}_{\mathrm{xy}}=\mu \mathrm{S}_{\mathrm{xy}} \quad, \quad \dot{\varepsilon}_{\mathrm{xz}}=\mu \mathrm{S}_{\mathrm{xz}} \quad, \quad \dot{\varepsilon}_{\mathrm{yz}}=\mu \mathrm{S}_{\mathrm{yz}}
\end{aligned}
$$

Where $\dot{\varepsilon}_{\mathrm{i}}$ and $\mathrm{S}_{\mathrm{i}}(\mathrm{i}=\mathrm{x}, \mathrm{y}, \mathrm{z})$ represent the direct strain rate and deviatoric stress along $\mathrm{i}$-axis respectively, $\dot{\varepsilon}_{\mathrm{ij}}$ and $\mathrm{S}_{\mathrm{ij}}(\mathrm{j}=\mathrm{x}, \mathrm{y}, \mathrm{z})$ the shear strain rate and stress associated with the plane (ij) respectively and $\mathrm{u}$ is the constant of proportionality. The symbol (') denotes the ordinary time derivative operator $(\mathrm{d} / \mathrm{dt})$. Employing the failure criteria by Von-Mises, on above equations, in case of perfect plastic deformation under pure yield shear stress (k) once, and again under uniaxial flow stress $\left(\sigma_{0}\right)$, would give:

$$
\begin{aligned}
& \frac{1}{2}\left(\mathrm{~S}_{\mathrm{x}}^{2}+\mathrm{S}_{\mathrm{y}}^{2}+\mathrm{S}_{\mathrm{z}}^{2}\right)+\left(\mathrm{S}_{\mathrm{xy}}^{2}+\mathrm{S}_{\mathrm{xz}}^{2}+\mathrm{S}_{\mathrm{yz}}^{2}\right)=\mathrm{k}^{2} \\
& \mathrm{k}=\frac{1}{\sqrt{3}} \sigma_{0}
\end{aligned}
$$

The substitution of eqs. (2) into above one yields: 


$$
\mu=\frac{1}{\mathrm{k}} \sqrt{\frac{1}{2}\left(\dot{\varepsilon}_{\mathrm{x}}^{2}+\dot{\varepsilon}_{\mathrm{y}}^{2}+\dot{\varepsilon}_{\mathrm{z}}^{2}\right)+\left(\dot{\varepsilon}_{\mathrm{xy}}^{2}+\dot{\varepsilon}_{\mathrm{xz}}^{2}+\dot{\varepsilon}_{\mathrm{yz}}^{2}\right)}=\frac{1}{\mathrm{k}} \sqrt{\frac{1}{2} \dot{\varepsilon}_{\mathrm{ij}} \dot{\varepsilon}_{\mathrm{ij}}}
$$

Noting that the last term, in above relations, represents the summation on all $\mathrm{i}$ and $\mathrm{j}$ with $\dot{\varepsilon}_{\mathrm{ii}}=\dot{\varepsilon}_{\mathrm{i}}$. Consequently, the increment of internal deformation power $\left(\mathrm{dW}_{\mathrm{i}}\right)$, per small volume $(d \nabla)$, which is expressed by:

$$
\frac{\partial \mathrm{W}_{\mathrm{i}}}{\partial \nabla}=\dot{\omega}=\left(\mathrm{S}_{\mathrm{x}} \dot{\varepsilon}_{\mathrm{x}}+\mathrm{S}_{\mathrm{y}} \dot{\varepsilon}_{\mathrm{y}}+\mathrm{S}_{\mathrm{z}} \dot{\varepsilon}_{\mathrm{z}}\right)+2\left(\mathrm{~S}_{\mathrm{xy}} \dot{\varepsilon}_{\mathrm{xy}}+\mathrm{S}_{\mathrm{xz}} \dot{\varepsilon}_{\mathrm{xz}}+\mathrm{S}_{\mathrm{yz}} \dot{\varepsilon}_{\mathrm{yz}}\right)
$$

May now be altered to the following one with the help of eqs. $(1,4)$ :

$$
\dot{\omega}=\frac{\mathrm{k}}{\sqrt{\frac{1}{2} \dot{\varepsilon}_{\mathrm{ij}} \dot{\varepsilon}_{\mathrm{ij}}}}\left\{\left(\dot{\varepsilon}_{\mathrm{x}}^{2}+\dot{\varepsilon}_{\mathrm{y}}^{2}+\dot{\varepsilon}_{\mathrm{z}}^{2}\right)+2\left(\dot{\varepsilon}_{\mathrm{xy}}^{2}+\dot{\varepsilon}_{\mathrm{xz}}^{2}+\dot{\varepsilon}_{\mathrm{yz}}^{2}\right)\right\}=2 \mathrm{k} \sqrt{\frac{1}{2} \dot{\varepsilon}_{\mathrm{ij}} \dot{\varepsilon}_{\mathrm{ij}}}
$$

Equating this result with the "equivalent internal power of deformation $\left(\dot{\omega}_{\text {eq }}\right)$ " for perfect plastic material of flow stress $\left(\sigma_{0}\right)$ and total strain $(\dot{\boldsymbol{\varepsilon}})$, which is:

$$
\dot{\omega}_{\mathrm{eq}}=\sigma_{0} \dot{\varepsilon}
$$

Will simply give:

$$
\dot{\varepsilon}=\sqrt{\frac{2}{3} \dot{\varepsilon}_{\mathrm{ij}} \dot{\varepsilon}_{\mathrm{ij}}}
$$

The multiplication of above formula by (dt) yields:

$$
\mathrm{d}^{2} \varepsilon=\frac{2}{3} \mathrm{~d} \varepsilon_{\mathrm{ij}} \mathrm{d} \varepsilon_{\mathrm{ij}}
$$

The right term, in above relation, can be split into two portions, one which represents the square of homogeneous strain increment $\left(\mathrm{d}^{2} \varepsilon_{\mathrm{H}}\right)$ and another represents the square of nonhomogeneous strain increment $\left(\mathrm{d}^{2} \varepsilon_{\mathrm{N}}\right)$, all expressed as:

$$
\begin{gathered}
\mathrm{d}^{2} \varepsilon=\mathrm{d}^{2} \varepsilon_{\mathrm{H}}+\mathrm{d}^{2} \varepsilon_{\mathrm{N}} \\
\mathrm{d} \varepsilon_{\mathrm{H}}=\sqrt{\frac{2}{3}\left(\mathrm{~d}^{2} \varepsilon_{\mathrm{x}}+\mathrm{d}^{2} \varepsilon_{\mathrm{x}}+\mathrm{d}^{2} \varepsilon_{\mathrm{x}}\right)} \quad, \quad \mathrm{d} \varepsilon_{\mathrm{N}}=\sqrt{\frac{4}{3}\left(\mathrm{~d}^{2} \varepsilon_{\mathrm{xy}}+\mathrm{d}^{2} \varepsilon_{\mathrm{xz}}+\mathrm{d}^{2} \varepsilon_{\mathrm{yz}}\right)}
\end{gathered}
$$

The $\left(\mathrm{d} \varepsilon_{\mathrm{H}}\right)$-expression, in above equation, stands as the main target function of Die profile design in the scope of present analysis, as does in other relevant works. The solving key consists of three main steps: (A) - expressing the direct strain increments in terms of the pass geometry dimensions, (B)- assuming a reasonable mathematical forms of $\left(\mathrm{d}_{\mathrm{H}}\right)$ variation with the position and lastly (C)- Solving the differential equation, comes out from the former two steps, for point-wise estimation of $\mathrm{h}(\mathrm{x})$.

\section{The Admissible Form Of $d \varepsilon_{\mathrm{h}}$ :}




\section{EVALUATION OF NEW HYPOTHETICAL CONCEPT (LHSIR) FOR DIE PROFILE DESIGN FOR HYDROSTATIC EXTRUSION OF AI/Mg COMPOUND}

The schematic cut view, in Fig.(2), shows a finitesimal $\mathrm{Al} / \mathrm{Mg}$ compound cylinders of material at location $(\mathrm{x})$, with length $(\mathrm{dx})$, mean circumference $(\mathrm{S})$, thickness $(\mathrm{h}(\mathrm{x}))$, crosssection area $(A)$, volume $(\mathrm{d} \nabla)$ with outer and inner radii (D0/2 and $\mathrm{R}(\mathrm{x})$ ) respectively), being executing some changes in length $\left(d^{\prime}\right)$, mean circumference $\left(S^{\prime}\right)$, thickness $\left(h(x)^{\prime}\right)$, crosssection area $\left(A^{\prime}\right)$, volume $\left(d \nabla^{\prime}\right)$ and corresponding radii and thickness (D0/2 and $\left.R(x)^{\prime}\right)$ respectively (shown far shifted for clarification).

The process is of axisymmetric type about $\mathrm{x}$-axis. Defining the average local strain $\left(\mathrm{d} \varepsilon_{\mathrm{x}}, \mathrm{d} \varepsilon_{\mathrm{y}}\right.$ and $\left.\mathrm{d} \varepsilon_{\mathrm{z}}\right)$ as:

$$
\mathrm{d} \varepsilon_{\mathrm{x}}=\frac{\mathrm{dx}^{\prime}-\mathrm{dx}}{\mathrm{dx}}, \mathrm{d} \varepsilon_{\mathrm{y}}=\frac{\mathrm{dh}^{\prime}-\mathrm{dh}}{\mathrm{dh}}, \mathrm{d} \varepsilon_{\mathrm{z}}=\frac{\mathrm{S}^{\prime}-\mathrm{S}}{\mathrm{S}}
$$

Expressing the individual parameters, at the right side, of above equation, in terms of localized geometrical properties or dimensions as followings:

$$
\mathrm{dx}^{\prime}=\frac{\mathrm{d} \nabla^{\prime}}{\mathrm{A}^{\prime}}, \mathrm{dx}=\frac{\mathrm{d} \nabla}{\mathrm{A}}, \mathrm{h}^{\prime}=\mathrm{h}-\mathrm{dh} \quad, \mathrm{S}=\pi\left(\frac{\mathrm{D}_{0}}{2}+\mathrm{R}\right), \mathrm{S}^{\prime}=\pi\left(\frac{\mathrm{D}_{0}}{2}+\mathrm{R}^{\prime}\right)
$$

And assuming the process to be under volume constancy condition (i.e, $d \nabla=d \nabla^{\prime}$ ), then eq.(11), with the aid of eq.(12), would be changed to:

$$
\mathrm{d} \varepsilon_{\mathrm{x}}=\frac{\mathrm{dA}^{\prime}}{\mathrm{A}}=\left(\frac{\mathrm{D}_{0}-2 \mathrm{~h}}{\mathrm{D}_{0}-\mathrm{h}}\right) \frac{\mathrm{dh}}{\mathrm{h}}, \mathrm{d} \varepsilon_{\mathrm{y}}=\frac{-\mathrm{dh}}{\mathrm{h}}, \mathrm{d} \varepsilon_{\mathrm{z}}=\frac{-\mathrm{dh}}{\left(\mathrm{D}_{0}-\mathrm{h}\right)}
$$

From which $\left(\mathrm{d} \varepsilon_{\mathrm{H}}\right)$, in eq. (10), could be expressed finally as:

$$
\mathrm{d} \varepsilon_{\mathrm{H}}=\frac{2}{\sqrt{3}} \frac{\sqrt{\left(3 \mathrm{~h}^{2}-3 \mathrm{D}_{0}+\mathrm{D}_{0}^{2}\right)}}{\left(\mathrm{D}_{0}-\mathrm{h}\right) \mathrm{h}} \mathrm{dh}
$$

\section{The Complete Solution $\varepsilon_{\mathrm{h}}=\mathbf{f}(\mathrm{h})$ :}

For all entire researchers, the complete solution of the ordinary differential eq. (14) is extracted from two unique sources, the first which is theoretically referred to Blanzynski ${ }^{(9)}$, and the second is concerned with the mathematical package MATLAB2011 (see for example Ref.[15]). The second one seems adequately simpler. Fortunately, one of present authors intended to take this role analytically during his supervision of M.Sc. dissertation (16). Accordingly, it is found that if a function in (h), say $(\psi)$, takes the form of:

$$
\psi=\frac{\left(\mathrm{D}_{0}-2 \mathrm{~h}\right)}{\sqrt{\left(3 \mathrm{~h}^{2}-3 \mathrm{D}_{0}+\mathrm{D}_{0}^{2}\right)}}
$$

then $\mathrm{h}(\mathrm{x})$, in result, could inversely take the form of:

$$
\mathrm{h}=\frac{\mathrm{D}_{0}}{2}\left\{1-\sqrt{\frac{\psi^{2}}{\left(4-3 \psi^{2}\right)}}\right\}
$$


The back substitution of $\mathrm{h}$, in above relation, into eq. (14) yields:

$$
\mathrm{d} \varepsilon_{\mathrm{H}}=\frac{-4}{\sqrt{3}} \frac{\mathrm{d} \psi}{\left(1-\psi^{2}\right)\left(4-3 \psi^{2}\right)}
$$

The factorial expansion, of the right side term in above equation, helps to solve for $\left(\mathrm{d} \varepsilon_{\mathrm{H}}\right)$ using the integration by parts technique as shown below:

$$
\int \mathrm{d} \varepsilon_{\mathrm{H}}=\frac{-4}{\sqrt{3}} \int\left[\frac{1}{2}\left\{\frac{1}{1-\psi}+\frac{1}{1+\psi}\right\}-\frac{3}{8}\left\{\frac{1}{1-\frac{\sqrt{3}}{2} \psi}+\frac{1}{1+\frac{\sqrt{3}}{2} \psi}\right\}\right] \mathrm{d} \psi
$$

The complete solution, of above equation, requires an initial condition to fix the constant of integration. Simply one can deduce that at Die entrance $\left(x=0, h=D_{0} / 2\right)$ and hence eq. (14) gives $(\psi=0)$, as well as the deformation there is onset, i.e $\left(\varepsilon_{\mathrm{H}}=0\right)$, and this implies the constant of integration, in eq. (18) vanishes. In result, the complete solution of former equation will be:

$$
\varepsilon_{\mathrm{H}}=\ln \left(\frac{1+\frac{\sqrt{3}}{2} \psi}{1-\frac{\sqrt{3}}{2} \psi}\right)\left(\frac{1-\psi}{1+\psi}\right)^{\frac{2}{\sqrt{3}}}
$$

too much precautions, one should take when adopting $\left(\varepsilon_{\mathrm{H}}\right)$ formula from relevant contexts and papers or when utilizing a mathematical package for solution, since some individual typed symbols or the standing feature of the exponent value, in that equation, are seemed no longer correct. The back derivation of eq. (19) is precisely yielding to the original form of eq. (7), and this proves the correctness of present formalization, unlike in other forms of solution which fail to satisfy this test.

\section{The Present Hypothetical Concept for Die Profile Design:}

Generally, the estimation of the Die ordinate $((\mathrm{R}(\mathrm{x}))$, from eq.(1) requires the preknowing of the corresponding value of $(\mathrm{h}(\mathrm{x}))$, and this in turn requires $(\psi)$ to be provided from eq.(16), and the former parameter needs $\left(\varepsilon_{\mathrm{H}}\right)$ to be given in advance to use eq.(19) by inverse numerical technique. Therefore, the one-way procedure to determine the Die ordinate at any position will be assessed by the back-way steps of: (A) proposing a reasonable value of $\left(\varepsilon_{\mathrm{H}}\right)$, (B) computing the corresponding $(\psi)$ value from eq. $(19),(\mathrm{C})$ determination of $(\mathrm{h}(\mathrm{x}))$ using eq.(16) and finally (D) estimation of ( $R(x))$ from eq.(1). This makes step (A) to be the unique essential one that should be achieved. Indeed, all design criteria differ, from each others, by the way of assessing the values of $\left(\varepsilon_{\mathrm{H}}\right)$ with position. The present concept (LHSIR) proposes that the ratio of two successive $\left(\varepsilon_{\mathrm{H}}\right)$ differences may no longer be constant, as does 


\section{EVALUATION OF NEW HYPOTHETICAL CONCEPT (LHSIR) FOR DIE PROFILE DESIGN FOR HYDROSTATIC EXTRUSION OF Al/Mg COMPOUND}

under the classical (CHRS) criteria, but posses some additional constant variation accumulated in the direction of x-axis making its function to be "linear" with position, in a stead of "constant". Specifically, if one selects (N) small equal divisions of the Die pass length $\left(1_{0}\right)$, each with length $\left(\Delta x=1_{0} / N\right)$, and the Die ordinates starting from the Die entrance with number $(\mathrm{i}=0)$ and ending at the exit $(\mathrm{i}=\mathrm{N})$, and if the difference of $\left(\varepsilon_{\mathrm{H}}\right)$ between any two adjacent positions (i+1 and i) takes the form of $\left(\Delta \varepsilon_{\mathrm{H}, \mathrm{i}+1}=\varepsilon_{\mathrm{H}, \mathrm{i}+1^{-}} \varepsilon_{\mathrm{H}, \mathrm{i}}\right)$ then the present (LHSIR) may start from proposing of:

$$
\begin{array}{r}
\Delta \varepsilon_{\mathrm{H}, \mathrm{i}+1}=\mathrm{S}_{\mathrm{i}} \Delta \varepsilon_{\mathrm{H}, \mathrm{i}} \quad, \quad \text { with } \mathrm{S}_{\mathrm{i}}=\mathrm{S}_{0}+\mathrm{i} . \mathrm{m}_{0} \text { for all } \mathrm{i}=0,1,2, \ldots . ., \mathrm{N} \\
\text { from which } \mathrm{m}_{0}=\frac{\mathrm{S}_{\mathrm{N}-2}-\mathrm{S}_{0}}{\mathrm{~N}-2}
\end{array}
$$

where $\left(\mathrm{S}_{0}\right)$ is a constant representing the initial increment ratio and $\left(\mathrm{m}_{0}\right)$ is another constant denotes the rate (slop) of these ratios along the Die length. In particular case one may expand the terms, in above formulae, to get:

$$
\begin{aligned}
& \frac{\varepsilon_{\mathrm{H}, 2}-\varepsilon_{\mathrm{H}, 1}}{\varepsilon_{\mathrm{H}, 1}-\varepsilon_{\mathrm{H}, 0}}=\mathrm{S}_{0}+0 \mathrm{~m}_{0}, \frac{\varepsilon_{\mathrm{H}, 3}-\varepsilon_{\mathrm{H}, 2}}{\varepsilon_{\mathrm{H}, 2}-\varepsilon_{\mathrm{H}, 1}}=\mathrm{S}_{0}+1 \mathrm{~m}_{0}, \frac{\varepsilon_{\mathrm{H}, 4}-\varepsilon_{\mathrm{H}, 3}}{\varepsilon_{\mathrm{H}, 3}-\varepsilon_{\mathrm{H}, 2}}=\mathrm{S}_{0}+2 \mathrm{~m}_{0} \quad, \ldots . . \\
& \frac{\varepsilon_{\mathrm{H}, \mathrm{i}+2}-\varepsilon_{\mathrm{H}, \mathrm{i}+1}}{\varepsilon_{\mathrm{H}, \mathrm{i}+1}-\varepsilon_{\mathrm{H}, \mathrm{i}}}=\mathrm{S}_{0}+\mathrm{im}_{0} \quad, \ldots, \frac{\varepsilon_{\mathrm{H}, \mathrm{N}-2}-\varepsilon_{\mathrm{H}, \mathrm{N}-1}}{\varepsilon_{\mathrm{H}, \mathrm{N}-1}-\varepsilon_{\mathrm{H}, \mathrm{N}}}=\mathrm{S}_{0}+(\mathrm{N}-2) \mathrm{m}_{0}
\end{aligned}
$$

from which all of $\left(\varepsilon_{\mathrm{H}, \mathrm{i}}, \mathrm{i}=2,3, \ldots, \mathrm{N}\right)$ may each be relating directly with $\left(\varepsilon_{\mathrm{H}, 1}\right)$ only and as followings (remembering that at the onset of deformation, i.e $\mathrm{x}=0$ then $\varepsilon_{\mathrm{H}, 0}=0$ ):

$$
\begin{aligned}
\varepsilon_{\mathrm{H}, 2}= & \left\{1+\mathrm{S}_{0}\right\} \varepsilon_{\mathrm{H}, 1} \quad, \quad \varepsilon_{\mathrm{H}, 3}=\left\{1+\mathrm{S}_{0}+\mathrm{S}_{0}\left(\mathrm{~S}_{0}+\mathrm{m}_{0}\right)\right\} \varepsilon_{\mathrm{H}, 1} \\
\varepsilon_{\mathrm{H}, 4}= & \left\{1+\mathrm{S}_{0}+\mathrm{S}_{0}\left(\mathrm{~S}_{0}+\mathrm{m}_{0}\right)+\mathrm{S}_{0}\left(\mathrm{~S}_{0}+\mathrm{m}_{0}\right)\left(\mathrm{S}_{0}+2 \mathrm{~m}_{0}\right)\right\} \varepsilon_{\mathrm{H}, 1} \\
\varepsilon_{\mathrm{H}, 5}= & \left\{1+\mathrm{S}_{0}+\mathrm{S}_{0}\left(\mathrm{~S}_{0}+\mathrm{m}_{0}\right)+\mathrm{S}_{0}\left(\mathrm{~S}_{0}+\mathrm{m}_{0}\right)\left(\mathrm{S}_{0}+2 \mathrm{~m}_{0}\right)+\mathrm{S}_{0}\left(\mathrm{~S}_{0}+\mathrm{m}_{0}\right)\left(\mathrm{S}_{0}+2 \mathrm{~m}_{0}\right)\right. \\
& \left.+\mathrm{S}_{0}\left(\mathrm{~S}_{0}+\mathrm{m}_{0}\right)\left(\mathrm{S}_{0}+2 \mathrm{~m}_{0}\right)\left(\mathrm{S}_{0}+3 \mathrm{~m}_{0}\right)\right\} \varepsilon_{\mathrm{H}, 1}
\end{aligned}
$$

.etc.

The set of eqs. (22) may be simplified alternatively into the simple forms of:

$$
\begin{aligned}
& \varepsilon_{\mathrm{H}, \mathrm{i}}=\mathrm{K}_{\mathrm{i}} \varepsilon_{\mathrm{H}, 1}, \mathrm{~K}_{\mathrm{i}}=1+\sum_{\mathrm{j}=0}^{\mathrm{i}-2} \mathrm{Q}_{\mathrm{j}} \text { for all }(\mathrm{i}=2,3, \ldots ., \mathrm{N}) \\
& \mathrm{Q}_{\mathrm{j}}=\mathrm{Q}_{\mathrm{j}-1}\left(\mathrm{~S}_{0}+\mathrm{jm}_{0}\right), \text { for all }(\mathrm{j}=0,1, \ldots ., \mathrm{N}-2) \text { with } \mathrm{Q}_{-1}=1
\end{aligned}
$$

noting that all of $\left(\mathrm{K}_{\mathrm{i}}\right)$ are depending only upon the given input data of $\left(\mathrm{S}_{0}\right.$ and $\left.\mathrm{m}_{0}\right)$. For estimation of all $\left(\varepsilon_{\mathrm{H}, \mathrm{i}}\right)$, from the first of eqs.(23), then the first numbered homogeneous strain $\left(\varepsilon_{\mathrm{H}, 1}\right)$ should be computed, and this can be done by applying the same formula on the last numbered homogeneous strain $\left(\varepsilon_{\mathrm{H}, \mathrm{N}}\right)$, i.e $\varepsilon_{\mathrm{H}, \mathrm{l}}=\varepsilon_{\mathrm{H}, \mathrm{N}} / \mathrm{K}_{\mathrm{N}}$. The value of $\left(\varepsilon_{\mathrm{H}, \mathrm{N}}\right)$ itself can be 
determined using eq. (15) to get firstly the corresponding $\left(\psi_{\mathrm{N}}\right)$ value (where $\left(\mathrm{h}_{\mathrm{N}}\right)$ is already known) and then applying eq.(19) inversely to obtain the necessary value of $\left(\varepsilon_{\mathrm{H}, \mathrm{N}}\right)$. By this, the four steps procedure, explained previously in this section, to establish the Die pass geometry, is completely clarified. The time comes now to quantify the different associated powers and the relative extrusion pressure for a Die of pass profile designed under the present (LHSIR) concept.

\section{The Present Theoretical Die Profiles (LHSIR):}

For present work purposes, three different sets of die profiles are theoretically designed under the present developed (LHSIR) concept, explained in detail in previous section, each set correspond to chosen values of the initial increment ratios $(\mathrm{S} 0=0.8,1.0,1.2)$ describing decelerating, uniform and accelerating of homogeneous strains with the $\mathrm{x}$-axis respectively. All the sets maintain seven chosen values of the increment ratio slope $(\mathrm{m} 0=-$ $0.6,-0.4,-0.2,0.0,0.2,0.4,0.6)$.

The special present case of $(\mathrm{m} 0=0.0)$ is the only one that could be also handled under the classical (CHSR) concept. Theoretically, all the present (3) die profiles have the same pass length $(10=20 \mathrm{~mm})$ and a stem diameter of $(30 \mathrm{~mm})$, whereas the inner surface of the container (D0) is taken equal $(50 \mathrm{~mm})$. This leads to $(\mathrm{h} 0=25 \mathrm{~mm})$ and $(\mathrm{h} 1=22.5 \mathrm{~mm}$ for die 45 $\mathrm{mm}, \mathrm{h} 1=20 \mathrm{~mm}$ for die $40 \mathrm{~mm}$ and $\mathrm{h} 1=17.5 \mathrm{~mm}$ for die $35 \mathrm{~mm}$ ). These dimensions are carefully fixed for manufacturing purposes coming in next section.

The die profile ordinates were twenty in number ( $\mathrm{i}, \mathrm{e} \mathrm{N}=20$ ) and their magnitudes were estimated, in accordance with the 4-steps procedure clarified previously, using an ( $\mathrm{PC} /$ interactive WinDaq program) and plotted with (Microsoft-Excel and MATLAB) software as shown in the three corresponding Figures of (6-1a,6-1b,6-1c).

\section{The Present Velocity Field and UPA:}

Basically, the approach concerns with computing of the individual powers of shear, friction and internal deformation relating to the corresponding zones of the process. The total sum these powers would be equated to the external one maintained by the ram, from which the predicted relative pressure, or the ram capacity, can be estimated. A distinct kind of power is much depending on the local strain rate which in turn relates with the point-wise velocity at given particular zone. Henceforth, a representation of the domain velocity field will be essential. For present analysis, the axi-symmetric velocity vector (v), of a finitesimal element will be composed of $\left(\mathrm{v}_{\mathrm{x}}>0\right)$ the component in $\mathrm{x}$-direction, and $\left(\mathrm{v}_{\mathrm{y}}>=0\right)$ in $\mathrm{y}$-direction as illustrated in Fig. (4) in which the vertical plane OA in the zone of entrance (zone-1) gives 
$\left(\mathrm{v}_{\mathrm{x}}=\mathrm{v}_{0}=\right.$ the Die speed $)$ and $\left(\mathrm{v}_{\mathrm{y}}=0\right)$. A similar situation is occurred for any part in the zone of exit (zone-3) where $\left(\mathrm{v}_{\mathrm{x}}=\mathrm{v}_{1}=\right.$ the extrusion exit velocity). In any case, the velocity component $\left(\mathrm{v}_{\mathrm{x}}\right)$, at any sectional area $\left(\mathrm{A}_{\mathrm{x}}\right)$ can be determined according to the continuity law which states:

$$
\mathrm{A}_{\mathrm{x}} \mathrm{v}_{\mathrm{x}}=\mathrm{C}=\mathrm{constant} \quad \text { where } \mathrm{A}_{\mathrm{x}}=\pi \mathrm{h}\left(2 \mathrm{~h}_{0}-\mathrm{h}\right)
$$

So for $(\mathrm{x}=0)$ then $\left(\mathrm{A} 0=\pi \mathrm{h}_{0}^{2}\right.$ and $\left.\mathrm{v}_{\mathrm{x}}=\mathrm{v}_{0}\right)$ from which eq. (24) serve to determine the value of (C) and accordingly yields:

$$
\mathrm{v}_{\mathrm{x}}=\mathrm{f}(\mathrm{x})=\frac{\mathrm{h}_{0}^{2}}{\mathrm{~h}\left(2 \mathrm{~h}_{0}-\mathrm{h}\right)}
$$

applied equally for all points within zone-2, whilst zone-1 and zone-3 are supposed to be relaxed from any change for this stage of analysis. The y-component of velocity vector may be then expressed generally as:

$$
\mathrm{v}_{\mathrm{y}}=\mathrm{f}(\mathrm{x}, \mathrm{y})
$$

Focusing on point $(\mathrm{p})$, on the Die profile in Fig. (3), whose coordinates are $\left(\mathrm{x}, \mathrm{y}_{0}=\mathrm{R}=\mathrm{h}_{0}-\mathrm{h}\right)$, the velocity vector $\left(\mathrm{v}_{\mathrm{p}}\right)$ is tangent to the profile (OC), i.e its y-component ( $\left.\mathrm{v}_{\mathrm{yp}}\right)$ must satisfy:

$$
\begin{aligned}
& \mathrm{v}_{\mathrm{yp}}=\mathrm{v}_{\mathrm{x}} \tan (\alpha) \quad \text { on the punch profile } \\
& \text { where } \tan (\alpha)=\frac{\mathrm{dh}}{\mathrm{dx}}
\end{aligned}
$$

and $(\alpha)$ denotes the slop of the Die pass surface at point $(\mathrm{p})$. Knowing that $\left(\mathrm{v}_{\mathrm{yp}}=0\right)$ at the adjacent point $(\mathrm{q})$, on the container inner surface $\left(\mathrm{y}=\mathrm{h}_{0}\right)$, then for linear variation supposition of $\left(\mathrm{v}_{\mathrm{yp}}\right)$ along the line $(\mathrm{pq})$ would give:

$$
\mathrm{v}_{\mathrm{y}}=\mathrm{v}_{\mathrm{x}} \tan (\alpha)\left(\frac{\mathrm{h}_{0}-\mathrm{y}}{\mathrm{h}}\right)
$$

To compute for shear and friction powers, on all boundaries of zone-2, one may use the general expression of these kinds of powers, (W) say, given as:

$$
\begin{aligned}
\mathrm{W} & =\int_{\mathrm{A}} \mathrm{ck}|\Delta \mathrm{v}| \mathrm{dA} \\
\text { where } \mathrm{c} & = \begin{cases}1 & \text { in shear } \\
\mathrm{m} & \text { in friction }\end{cases}
\end{aligned}
$$

with $(\mathrm{m})$ represents the actual friction coefficient, $[\Delta \mathrm{v}]$ the absolute value of velocity resultant, acting on small elementary area $(\mathrm{dA})$, along the chosen boundary where the integration is naturally carried out. Thus, on the entrance boundary (OA), one may express $[\Delta \mathrm{v}], \mathrm{dA}$ and hence the shear power $\left(\mathrm{W}_{\mathrm{si}}\right)$, in accordance to eq. (29), to be: 


$$
\begin{gathered}
\mathrm{dA}=2 \pi \mathrm{ydy} \quad,|\Delta \mathrm{v}|=\mathrm{v}_{0} \tan (\alpha)\left(\frac{\mathrm{h}_{0}-\mathrm{y}}{\mathrm{h}_{0}}\right) 0 \leq \mathrm{y} \leq \mathrm{h}_{0} \\
\mathrm{~W}_{\mathrm{si}}=\frac{1}{3} \pi \mathrm{kv}_{0} \mathrm{~h}_{0}^{2} \tan \left(\alpha_{0}\right)
\end{gathered}
$$

while on exit boundary $(\mathrm{BC})$, the associate parameters and the shear power $\left(\mathrm{W}_{\mathrm{se}}\right)$ will be:

$$
\begin{gathered}
\mathrm{dA}=2 \pi \mathrm{ydy} \quad,|\Delta \mathrm{v}|=\mathrm{v}_{0} \tan (\alpha)\left(\frac{\mathrm{h}_{0}-\mathrm{y}}{\mathrm{h}_{1}}\right) \mathrm{h}_{0}-\mathrm{h}_{1} \leq \mathrm{y} \leq \mathrm{h}_{0} \\
\mathrm{~W}_{\mathrm{se}}=\frac{1}{3} \pi \mathrm{kv}_{0} \mathrm{~h}_{1}\left(3 \mathrm{~h}_{0}-2 \mathrm{~h}_{1}\right) \tan \left(\alpha_{1}\right)
\end{gathered}
$$

On the Die pass surface $(\mathrm{OC})$, the mentioned parameters and the friction power $\left(\mathrm{W}_{\mathrm{fp}}\right)$ will take the forms of:

$$
\begin{gathered}
\mathrm{dA}=2 \pi \mathrm{yds},|\Delta \mathrm{v}|=\frac{\mathrm{v}_{\mathrm{x}}}{\cos (\alpha)}=\mathrm{v}_{0} \frac{\mathrm{h}_{0}^{2}}{\mathrm{~h}\left(2 \mathrm{~h}_{0}-\mathrm{h}\right)} \frac{1}{\cos (\alpha)} \\
\mathrm{W}_{\mathrm{fp}}=2 \pi \mathrm{mkv}_{0} \int_{\substack{\mathrm{x}=0 \\
\mathrm{~h}=\mathrm{h}_{0}}}^{\substack{\mathrm{h}=\mathrm{I}_{0} \\
\mathrm{~h}}} \frac{\mathrm{h}_{0}^{2}\left(\mathrm{~h}_{0}-\mathrm{h}\right)}{\mathrm{h}\left(2 \mathrm{~h}_{0}-\mathrm{h}\right)} \frac{1}{\cos ^{2}(\alpha)} \mathrm{dx} \quad \ldots . .(32)
\end{gathered}
$$

Noting that the integration process, in above relation, may be done using a proper numerical technique. On the container inner surface $(\mathrm{AB})$, those parameters and the friction power $\left(\mathrm{W}_{\mathrm{fc}}\right)$ can be written as:

$$
\begin{aligned}
& \mathrm{dA}=2 \pi \mathrm{h}_{0} \mathrm{dx} \quad,|\Delta \mathrm{v}|=\mathrm{v}_{0} \frac{\mathrm{h}_{0}^{2}}{\mathrm{~h}\left(2 \mathrm{~h}_{0}-\mathrm{h}\right)} \\
& \mathrm{W}_{\mathrm{fc}}=2 \pi \mathrm{mkv}_{0} \int_{\substack{\mathrm{x}=0 \\
\mathrm{~h}=\mathrm{h}_{0}}}^{\substack{\mathrm{x}=\mathrm{I}_{0} \\
\mathrm{~h}=\mathrm{h}_{1}}} \frac{\mathrm{h}_{0}^{3}}{\mathrm{~h}\left(2 \mathrm{~h}_{0}-\mathrm{h}\right)} \mathrm{dx}
\end{aligned}
$$

The last kind of power is the internal deformation one $\left(\mathrm{W}_{\mathrm{i}}\right)$, associating with zone-2 domain. The general expression of such power may take the form of:

$$
\begin{gathered}
\mathrm{W}_{\mathrm{i}}=\int_{\nabla} 2 \mathrm{k} \sqrt{\frac{1}{2} \dot{\varepsilon}_{\mathrm{ij}} \dot{\varepsilon}_{\mathrm{ij}}} \mathrm{d} \nabla \\
\mathrm{d} \nabla=2 \pi \mathrm{ydydx} \quad 0 \leq \mathrm{x} \leq \mathrm{l}_{0}, \quad \mathrm{~h}_{0}-\mathrm{h} \leq \mathrm{y} \leq \mathrm{h}_{0}
\end{gathered}
$$

In above equation, the three components of direct strain rate (i.e $\dot{\varepsilon}_{\text {ii }}$ ) can be formulized, using eqs.(13) after dividing by (dt) and simplifying the results with the help of eqs. $(22,28)$, to give: 


$$
\begin{aligned}
& \dot{\varepsilon}_{\mathrm{x}}=\left(\frac{\mathrm{D}_{0}-2 \mathrm{~h}}{\mathrm{D}_{0}-\mathrm{h}}\right) \mathrm{v}_{\mathrm{y}}, \dot{\varepsilon}_{\mathrm{y}}=\frac{-1}{\mathrm{~h}} \mathrm{v}_{\mathrm{y}}, \dot{\varepsilon}_{\mathrm{z}}=\frac{-1}{\left(\mathrm{D}_{0}-\mathrm{h}\right)} \mathrm{v}_{\mathrm{y}} \\
& \mathrm{v}_{\mathrm{y}}=\frac{\mathrm{dh}}{\mathrm{dt}}=\mathrm{v}_{0} \frac{\mathrm{h}_{0}^{2}}{\mathrm{~h}\left(\mathrm{D}_{0}-\mathrm{h}\right)} \tan (\alpha)\left(\frac{\mathrm{h}_{0}-\mathrm{y}}{\mathrm{h}}\right)
\end{aligned}
$$

The remaining components of shear strain rate (i.e $\dot{\boldsymbol{\varepsilon}}_{\mathrm{ij}}, \mathrm{i} \neq \mathrm{j}$ ) are all vanishes because of axisymmetricity of the process, except for the component $\left(\dot{\boldsymbol{\varepsilon}}_{\mathbf{x y}}\right)$ where its expression can be established from the partial derivatives of displacement components $(\mathrm{u}, \mathrm{v})$ in $(\mathrm{x})$ and $(\mathrm{y})$ direction respectively as followings:

$$
\begin{gathered}
\dot{\varepsilon}_{\mathrm{xy}}=\frac{\mathrm{d}}{\mathrm{dt}}\left(\frac{\partial \mathrm{u}}{\partial \mathrm{y}}+\frac{\partial v}{\partial \mathrm{x}}\right)=\frac{\partial}{\partial \mathrm{y}}\left(\frac{\mathrm{du}}{\mathrm{dt}}\right)+\frac{\partial}{\partial \mathrm{x}}\left(\frac{\mathrm{d} v}{\mathrm{dt}}\right) \\
\text { but } \mathrm{v}_{\mathrm{x}}=\frac{\mathrm{du}}{\mathrm{dt}} \text { and } \mathrm{v}_{\mathrm{y}}=\frac{\mathrm{d} v}{\mathrm{dt}} \\
\therefore \dot{\varepsilon}_{\mathrm{xy}}=\frac{\partial \mathrm{v}_{\mathrm{x}}}{\partial \mathrm{y}}+\frac{\partial \mathrm{v}_{\mathrm{y}}}{\partial \mathrm{x}}
\end{gathered}
$$

Referring to eq. (25), the first term, in above relation vanishes. Thus the shear strain rate components are simplified as:

$$
\dot{\varepsilon}_{\mathrm{xy}}=\frac{\partial \mathrm{v}_{\mathrm{y}}}{\partial \mathrm{x}}, \dot{\varepsilon}_{\mathrm{xz}}=0, \dot{\varepsilon}_{\mathrm{yz}}=0
$$

Collecting all the six $\left(\dot{\boldsymbol{\varepsilon}}_{\mathrm{ij}}\right)$ components, in eqs. $(34,36)$, and applying eq. (33), will be result in:

$$
\begin{gathered}
\mathrm{W}_{\mathrm{i}}=4 \pi \mathrm{k} \int_{\mathrm{x}=0}^{\mathrm{x}=\mathrm{I}_{0}} \int_{\mathrm{y}=\mathrm{h}_{0}-\mathrm{h}}^{\mathrm{y}=\mathrm{h}_{0}} \overline{\mathrm{W}}_{\mathrm{i}} \mathrm{ydydx} \\
\text { where } \overline{\mathrm{W}}_{\mathrm{i}}=\left\{\left(\frac{\sqrt{3 \mathrm{~h}^{2}-3 \mathrm{D}_{0} \mathrm{~h}+\mathrm{D}_{0}^{2}}}{\mathrm{~h}^{2}\left(\mathrm{D}_{0}-\mathrm{h}\right)^{2}}\right) \mathrm{v}_{\mathrm{y}}^{2}+\left(\frac{\partial \mathrm{v}_{\mathrm{y}}}{\partial \mathrm{x}}\right)^{2}\right\}^{\frac{1}{2}}
\end{gathered}
$$

Again here, the double integration process, in the first of eqs. (37), can be achieved by a suitable numerical technique, with the use of approximation:

$$
\frac{\partial \mathrm{v}_{\mathrm{y}}}{\mathrm{dx}} \approx \frac{\left|\mathrm{v}_{\mathrm{y}}\right|_{\mathrm{x}+\Delta \mathrm{x}}-\left|\mathrm{v}_{\mathrm{y}}\right|_{\mathrm{x}}}{\Delta \mathrm{x}} \text { for } \Delta \mathrm{x}=\frac{1_{0}}{\mathrm{~N}}
$$

At the end, the summation of overall types of powers, given by eqs. $(30-32,37)$, results in the total power of deformation $\left(\mathrm{W}_{\mathrm{T}}\right)$ as:

$$
\begin{gathered}
\mathrm{W}_{\mathrm{T}}=\mathrm{W}_{\mathrm{i}}+\mathrm{W}_{\mathrm{s}}+\mathrm{W}_{\mathrm{f}} \\
\text { where } \mathrm{W}_{\mathrm{s}}=\mathrm{W}_{\mathrm{si}}+\mathrm{W}_{\mathrm{se}} \text { and } \mathrm{W}_{\mathrm{f}}=\mathrm{W}_{\mathrm{fp}}+\mathrm{W}_{\mathrm{fc}}
\end{gathered}
$$


And which is expected to be equal to the external forming power $\left(\mathrm{W}_{\mathrm{E}}\right)$, executed by the ram of pressure $(\mathrm{P})$, acting on the projected area $\left(\mathrm{A}_{0}\right)$ and moving with speed $\left(\mathrm{v}_{0}\right)$. In other words this may be written as:

$$
\mathrm{W}_{\mathrm{E}}=\mathrm{PA}_{0} \mathrm{v}_{0}=\mathrm{W}_{\mathrm{T}}
$$

Dividing all expanding terms, in above relation, by $\left(\sigma_{0} \mathrm{~A}_{0} \mathrm{v} 0=\mathrm{W}_{0}\right)$ which denotes simply the equivalent homogeneous power, and arranging conveniently, then one would obtain:

$$
\left(\frac{\mathrm{P}}{\sigma_{0}}\right)=\left(\frac{\mathrm{W}_{\mathrm{i}}}{\mathrm{W}_{0}}\right)+\left(\frac{\mathrm{W}_{\mathrm{s}}}{\mathrm{W}_{0}}\right)+\left(\frac{\mathrm{W}_{\mathrm{f}}}{\mathrm{W}_{0}}\right)
$$

Noting that all terms, in above equation, are non-dimensional quantities. For simplicity, one may introduce alternative notations, $(\eta)$ say, to represents these terms as:

$$
\begin{gathered}
\eta_{\mathrm{P}}=\eta_{\mathrm{i}}+\eta_{\mathrm{s}}+\eta_{\mathrm{f}} \\
\text { where } \eta_{\mathrm{P}}=\frac{\mathrm{P}}{\sigma_{0}}, \eta_{\mathrm{i}}=\frac{\mathrm{W}_{\mathrm{i}}}{\mathrm{W}_{0}}, \eta_{\mathrm{s}}=\frac{\mathrm{W}_{\mathrm{s}}}{\mathrm{W}_{0}} \text { and } \eta_{\mathrm{f}}=\frac{\mathrm{W}_{\mathrm{f}}}{\mathrm{W}_{0}}
\end{gathered}
$$

By this, $\left(\eta_{\mathrm{P}}\right)$ denotes the relative extrusion pressure (the present main objective), $\left(\eta_{\mathrm{i}}\right)$ the relative internal power, $\left(\eta_{\mathrm{s}}\right)$ the relative shear power and finally $\left(\eta_{\mathrm{f}}\right)$ the relative friction power.

\section{3- EXPERIMENTAL WORK:}

Much concentration was paid on manufacturing of (13) different Dies together with a complementary setup unite of die upper and lower plates, punch holder and the guide pins, all were heat treated to provide a compact experiment system for hydrostatic extrusion of a model material of pure lead $(0.01 \%$ impurities, $12 \mathrm{MPa}$ flow stress and 0.2 friction coefficient as familiarly adapted from relevant sources $[15,16]$. Fig. (5) shows a photograph of the present manufactured Dies under consideration. Since much of history is well-known, the reader can refer to former references for more details of manufacturing procedure and material properties confirmation. The Dies were carefully sized by lathe operation and then formed by CNC-machine to produce their profile shapes under the new (LHSIR) concept. Finally all were again heat treated to reach a reasonable level of hardenity and surface finished by grind machine. This job was conducted at Al-Nasr general company of mechanical industry, whereas the extrusion process was accomplished at the manufacturing laboratory of University of Technology, using a universal testing machine with a load capacity not exceeding (3 tones). 


\section{EVALUATION OF NEW HYPOTHETICAL CONCEPT (LHSIR) FOR DIE PROFILE DESIGN FOR HYDROSTATIC EXTRUSION OF Al/Mg COMPOUND}

\section{4- THE NUMERICAL AND EXPERIMENTAL RESULTS:}

The three curves in Fig.(6) illustrate the present numerical outputs of relative extrusion pressure $\left(\eta_{P}\right)$ as the main present objective, for three selected values of $\left(S_{0}\right)$ as varied with seven typical values of $\left(\mathrm{m}_{0}\right)$ mentioned in former section. A side of this setting of design parameters range $\left(\mathrm{S}_{0}, \mathrm{~m}_{0}\right)$, the theoretical results were devoted to not exceed a value of (5.5) which overestimates the allowable limit of the actual ram capacity (3 tones) for the processed billet material.

The present experiment, with theoretical, outputs are summarized in Table (1) where ten tests were conducted for all the Dies ( of three values of $S_{0}, m_{0}$ and one commercially tapered, i.e $3 \times 3+1=10)$. One may note that the Die of $\left(\mathrm{S}_{0}=1, \mathrm{mo}=0.0\right)$ is precisely referring to a conical profile Die (tapered). This duplication of results are made for validity comparison of the present $\mathrm{CNC}$ manufacturing of the sample and the correspondent one from commercial markets.

\section{5- DISCUSSIONS AND CONCLUSIONS}

Theoretically, the significant difference between the developed (LHSIR) and the classical (CHSR) concepts, is essentially referred to the new inclusion of an increment ratio slop $\left(\mathrm{m}_{0}\right)$ within the content of the design criteria. Its role is very appreciably noticed in Fig. (6) where the changes in individual relative extrusion pressure are very obvious as $\left(\mathrm{m}_{0}\right)$ changes from negative to positive values. Specifically for $\left(\eta_{\mathrm{P}}\right)$, the figure shows also that a Die of negative $\left(\mathrm{m}_{0}\right)$ requires higher relative power when $\left(\mathrm{S}_{0}\right)$ is smaller (falling behavior), in contrary with that of positive value (rising behavior). Except of the Die of ( $\left.S_{0}=0.6\right)$, where a continuously decrease, of $\left(\eta_{P}\right)$ with $\left(m_{0}\right)$, is observed, all others show an "optimum point" of minimum $\left(\eta_{P}\right)$ value within close small range of $\left(m_{0}\right)$. Actually, one may see that $\left(m_{0}=-0.01\right)$ provides the new case of optimization in literature for this scope of analysis.

In numerals, Table (1) gives an adequate comparison of present theoretical and experimental results of $\left(\eta_{\mathrm{P}}\right)$ for three selected values of the mentioned ten Dies. A standard deviation parameter (SD) is included to quantify the differences mean between experimental and theoretical results, as a good indicator of validity checking of present entire work. As seen, these deviations are reasonably acceptable and almost changed with $\left(\mathrm{S}_{0}\right)$ values, from (0.01) in minimum to (0.30) in maximum. Nevertheless, these small variations might be referred to probable small uncertainty of the experiment setup procedure and/or the little variance of the velocity field representation from the actual state in practice. 


\section{CONCLUSIONS}

In closing remarks, one may list-down four main conclusions, arise from present work, as:

1. The present developed (LHSIR) concept presents a distinguished parameter $\left(\mathrm{m}_{0}\right)$ plays an important role to quantify the extrusion ram capacity, much effectively than other ones within the content of the classical (CHSR) concept.

2. The new proposition of velocity vector field, in the content of (UBA), is easier to be handled and simpler in formality than those found in literature.

3. A unique case of "optimization" is noticed to achieve minimum relative pressure level when the Die design parameter $(\mathrm{m} 0)$ is taken approximately equal (-0.01).

4. The present hypothetical concept are successful to achieve standard variations, of the relative pressure with the correspondents in experiment, falling within an acceptable range of values $(0.01-0.30)$.

\section{REFERENCES}

1- Ghosh A. \& Mallik A.K., Manufacturing Science, 2000, Khana Publishers, New Delhi.

2- Schey J.A., Introduction to Manufacturing Processes, 2000, McGraw-Hill Co., Singapore, $3^{\text {rd }}$ Edition.

3- Blazynski T.Z., Plasticity And Modern Metal Forming Technology, 1989, Elsevier Applied Science Publishers, London \& New York.

4- $\quad$ Avitzure B., Metal Forming, Report, 2003, University Of Lehieh, USA.

5- Moneer H. Tolephih Al-Saady, Kamal M.K. Al- Saify and Younis F. Al-Abdullah, "Evaluation Of New Hypothetical Concept (LHSIR) For Die Profile Design For Indirect Extrusion of Hollow Rods", European Journal of Scientific Research ISSN 1450-216X Vol.44 No.2 (2010), pp.188-203,EuroJournals Publishing, Inc. 2010. http://www.eurojournals.com/ejsr.htm

6- Mohamed J.H. \& Jawad A. A., "An Investigation Of The Effect Of Extrusion Die Design On The Level Of Redundant Shearing Stress Using Equivalent Strain Method", 2001, J. Engg. \& Tech., No. 4, Vol. 20, pp. 118-122.

7- Yong-Ming G. et al, "Analysis of Hot Forward-Backward Extrusion by the ViscoPlastic Finite Element Method", 1993, J. Mat. Proc. Tech., Vol. 38, pp. 103-114.

8- Al-Bayaty H.A., Stress \& Deformation Analysis of Extrusion Using FEM, 2000, Ph. 
D Thesis, University Of Technology, Iraq.

9- Vaidyanathan P.V. \& Blazynski T.Z., "A Theoretical Method Of Efficient Extrusion Die Design", 1983, J. Inst. \& Mat., Vol. 101, pp. 79-84.

10- Blazynski T.Z., Design of Tools for Deformation Processes, 1988, Elsevier Applied Science Publishers, London \& New York.

11- Chen C. \& Ling F., "Upper Bound Solution to Axsisymmetric Extrusion Problems", 1968, Int. J. Mech. Sci., Vol. 15, pp. 863-879.

12- Samanta S.K., "A New Die Profile with High Process Efficiency", 1971, J. Appl. Sci., Res. 25, pp. 54-64.

13- Johnson W. \& Millor P., Engineering Plasticity, 1980, Van Nastrand Rienhold Co., London.

14- Avitzure B. \& Pachlaw, "The Upper Bound Approach to Plane Strain Problem Using Linear \& Rotational Velocity Field. Part II: Basic Concepts", 1986, J. Engg. Ind., Vol. 108 , p. 295.

15- Shahab A.F., Investigation of the Pass Geometry in Compound Backward-Forward Extrusion Process", 2004, Ph.D. Thesis University Of Technology, Iraq.

16- Al-Abdulla Y.F., New Design of Punch Profile for an Indirect Extrusion with Application of the Upper Bound Approach", 2005, M.Sc. dissertation, The Technical College-Baghdad, Iraq.

Table (1): The present experimental \& theoretical results of $\left(\eta_{\mathrm{P}}\right)$ for different Die profiles, under the new (LHSIR) design concept.

\begin{tabular}{|c|c|c|c|c|c|}
\hline \multirow{2}{*}{\multicolumn{2}{|c|}{$\begin{array}{c}\text { (LHSIR) Die } \\
\text { Design Parameters }\end{array}$}} & \multirow{2}{*}{$\begin{array}{l}\text { Experimental } \\
\text { Max. Ram } \\
\text { Load }(\mathrm{Kg})\end{array}$} & \multicolumn{2}{|c|}{ Relative Pressure } & \multirow{2}{*}{$\begin{array}{c}\text { Standard } \\
\text { Deviation } \\
\left(\mathrm{S}_{\mathrm{D}}\right)^{*}\end{array}$} \\
\hline & & & Experimental & Theoretical & \\
\hline \multirow{3}{*}{$\mathrm{S}_{0}=0.8$} & $\mathrm{~m}_{0}=-0.04$ & 920 & 2.9967 & 3.0104 & \multirow{3}{*}{0.0112} \\
\hline & $\mathrm{m}_{0}=0.0$ & 740 & 2.4104 & 2.4400 & \\
\hline & $\mathrm{m}_{0}=0.04$ & 805 & 2.6221 & 2.6930 & \\
\hline \multirow{3}{*}{$\mathrm{S}_{0}=1.0$} & $\mathrm{~m}_{0}=-0.04$ & 810 & 1.9859 & 2.2657 & \multirow{3}{*}{0.2567} \\
\hline & $\mathrm{m}_{0}=0.0$ & 390 & 1.2703 & 1.3279 & \\
\hline & $\mathrm{m}_{0}=0.04$ & 1055 & 3.4690 & 3.6616 & \\
\hline \multirow{3}{*}{$\mathrm{S} 0=1.2$} & $\mathrm{~m}_{0}=-0.04$ & 565 & 1.6403 & 1.8669 & \multirow{3}{*}{0.1033} \\
\hline & $\mathrm{m}_{0}=0.0$ & 560 & 1.6240 & 1.8666 & \\
\hline & $\mathrm{m} 0=0.04$ & 1320 & 4.2996 & 4.3485 & \\
\hline \multicolumn{2}{|c|}{$\begin{array}{l}\text { Commercial } \\
\text { Tapered Die }\end{array}$} & 475 & 1.3729 & 1.3279 & 0.0450 \\
\hline
\end{tabular}




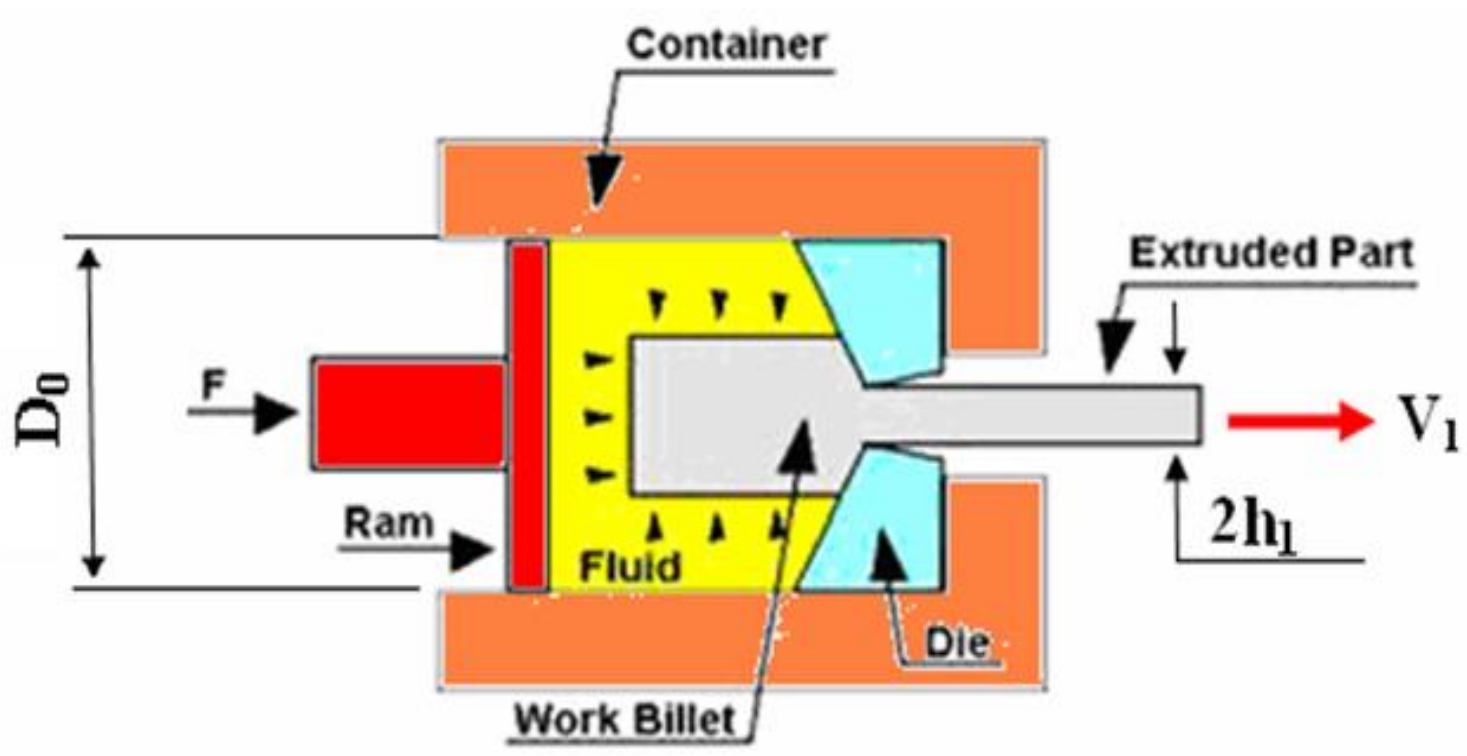

(a) Flat Die

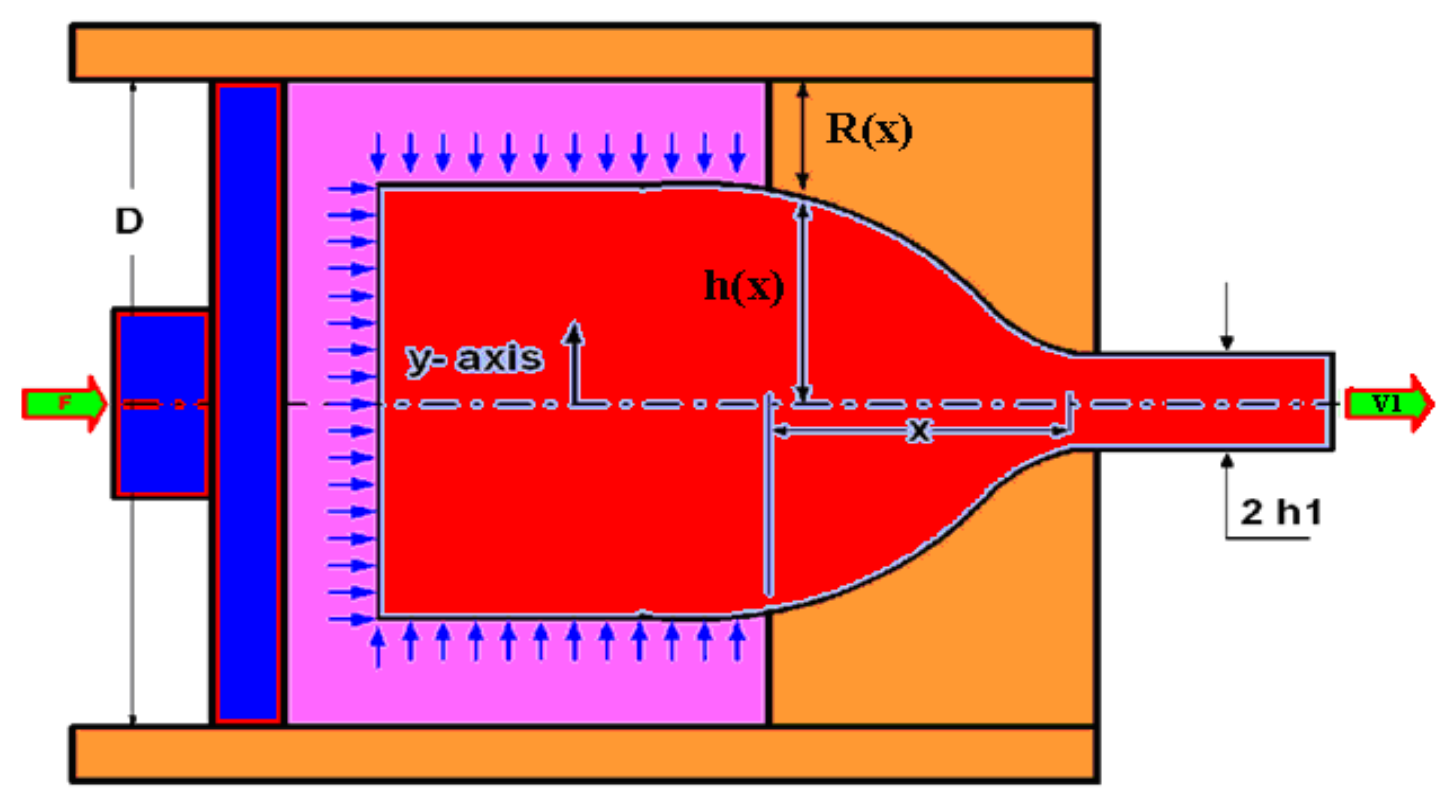

b) Evaluation of New Hypothetical Concept (LHSIR) for Die Profile Design for hydrostatic extrusion of $\mathrm{Al} / \mathrm{Mg}$ Compounds (die of typical pass geometry)

Figure (1): Schematic drawing of hydrostatic extrusion using (a) Flat die and (b) Die of typical pass geometry (Curvilinear die). 


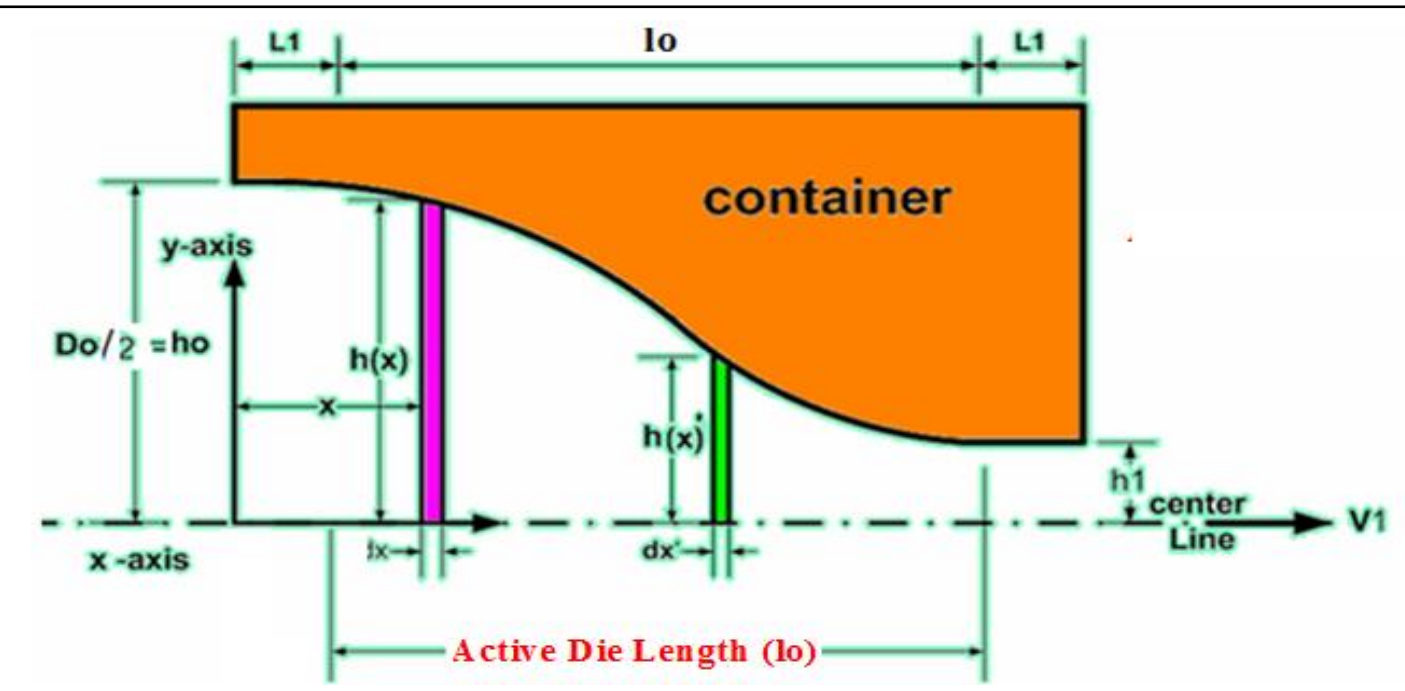

Figure (2): A cut view (half plane) showing a small slab (left) executing deformation (right) within (dt) time interval (at same position).

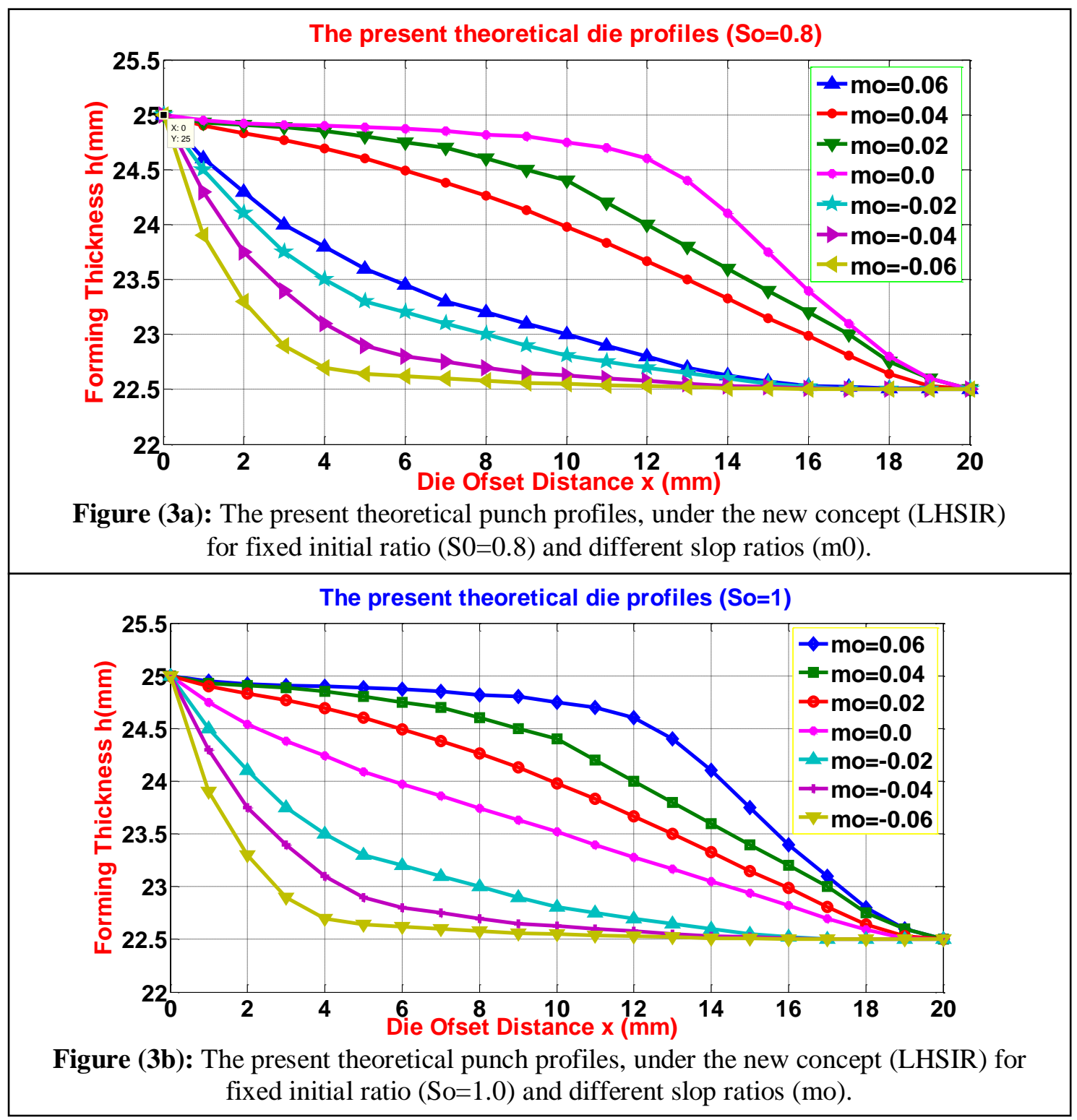




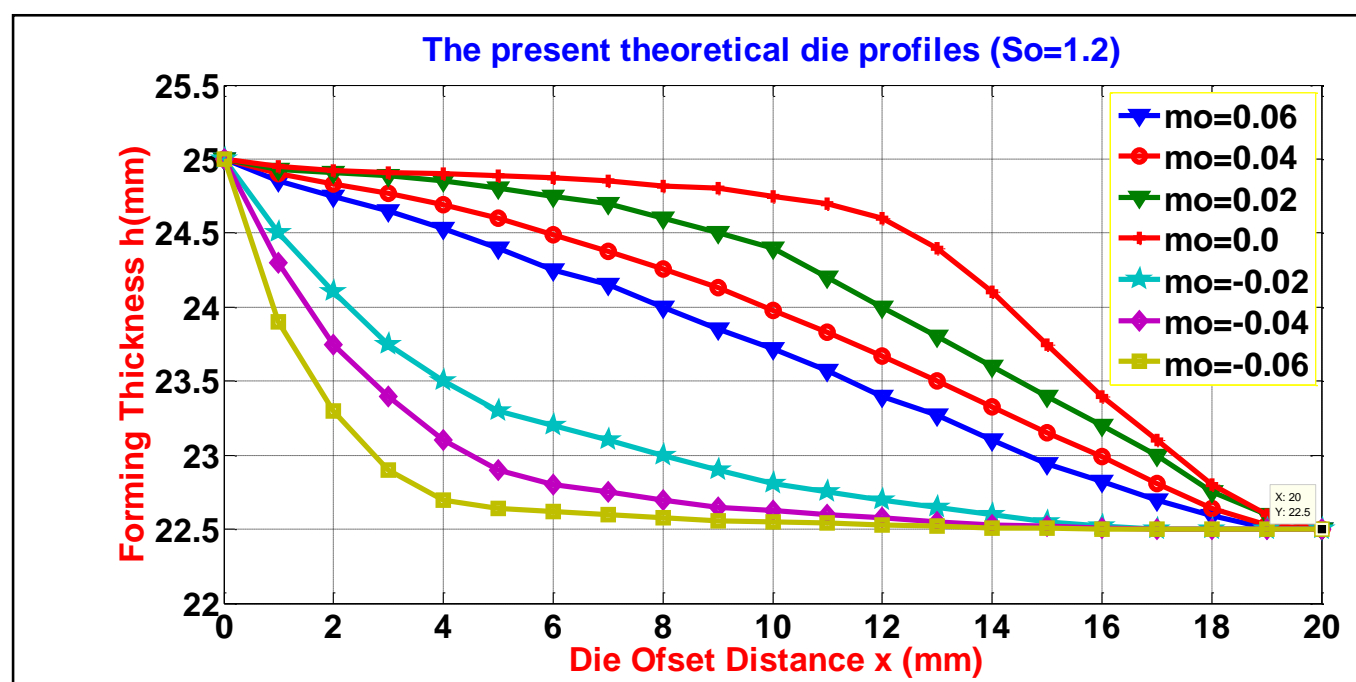

Figure (3c): The present theoretical punch profiles, under the new concept (LHRS) for fixed initial ratio $(\mathrm{So}=1.2)$ and different slop ratios $(\mathrm{mo})$.

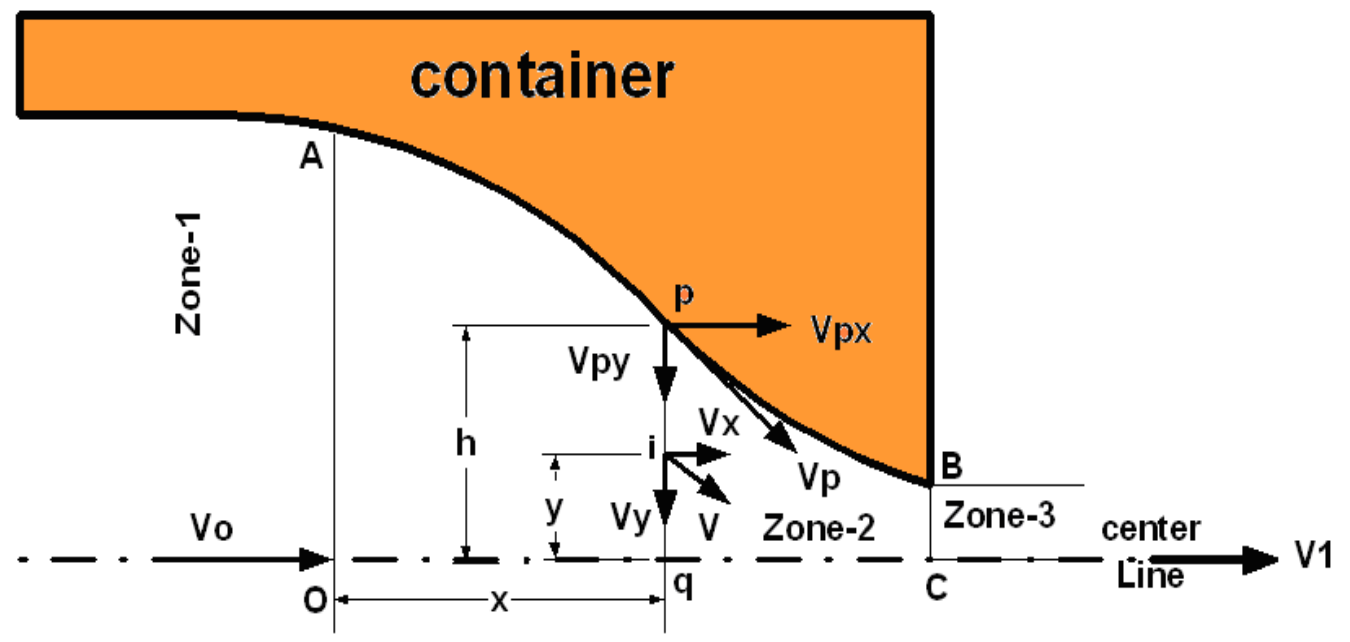

Figure (4): The point-wise velocity vectors representation for deformation zone-2 (OABC). 


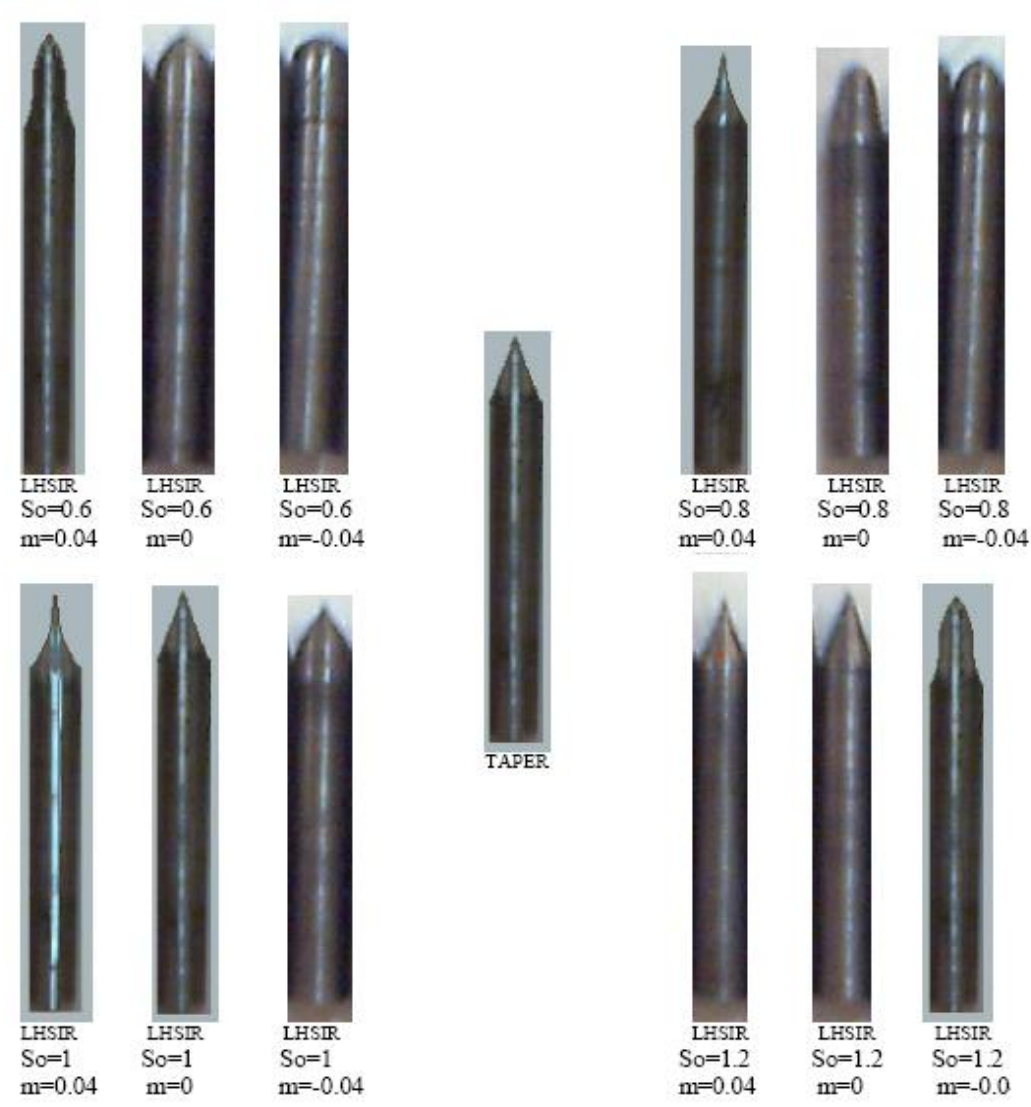

Figure (5): The present manufactured twelve Dies, under (LHSIR) concept, with additional commercial one (tapered).

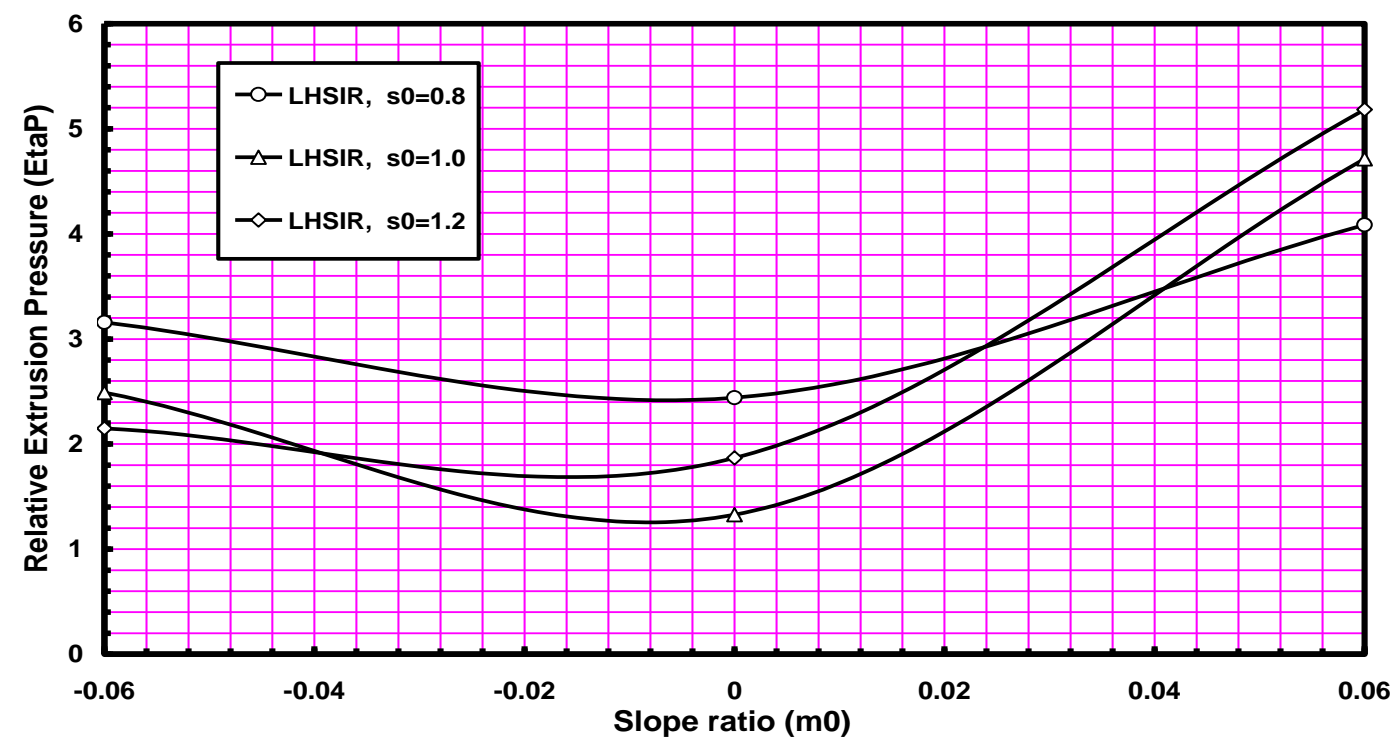

Fig.(6). The ram pressure ratio (EtaP) for variety of present punch profile shapes (under LHSIR concepts) as varied within a selected interval of the slope ratio $(\mathrm{m} 0)$. 


\section{مفهوم منطور جديد لتصميم قالب يستخدم البثق الهيدروستانيكي للاسطوانات المركبة من المغنيسيوم والالمنيوم (gM/IA)}

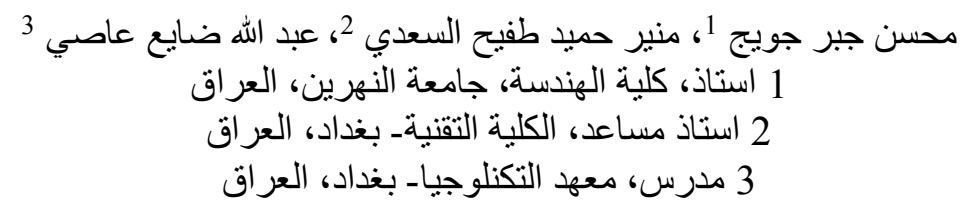

الخلاصة - ماصة

وجد في الادبيات طريقة اساسية لنوليد خط انسياب القالب ويقيم عدديا لتحديد نسبة الضغط النسبي كعامل رئيسي لتدقيق الاداء اعتمادا على طريقة الحدى العليا المشهورة. بينما البحث الحالي بطرح مفهوم منظور جديد لتصميم

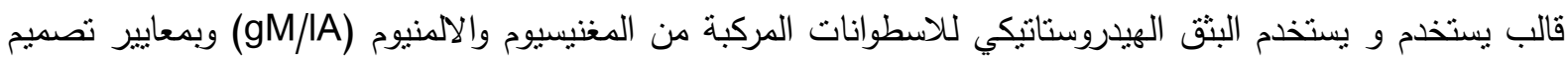
جديدة تقترح الخطية(ytiraeniL) لنسبة زيادة الانفعالات المتعاقبة المتجانسة (RISHL) للمادة المشكلة بدلا من مفهوم الثبات "ycnatsnoC" (RISHC). ان ثمرة العمل مركزة على دراسة تأثير عوامل البثق الهيدروستانيكي للحصول على لفي

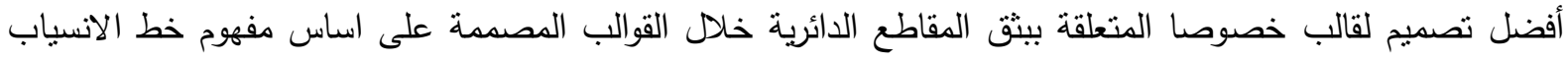
بالاعتماد على التحليل الرياضي والذي يمثل اشتقاق دالة الهدف نسبة الى متغيرات القالب وهناك سمه منطورة بشكل كبير في حقل السرعة تجعل الحسابات الضرورية المعقدة تتفذ بنجاح وقد تم تصنيع 12 عينة من الفولاذ التجاري بماكنة والتي عولجت حراريا لاختبار السبيكة الرئيسية المركبة من المغنيسيوم والالمنيوم (CNC) الصداحية والمقارنة. تخرج الخاتمة الرئيسية من هذا العمل بأن هناك خلاف صغير في معايير الثبات الكلاسيكية لتصميم القالب الذي يكون حساس جدا لتغيير المسنويات المتوقعة لنسب الضغط النسبية لعملية البثق الهيدروستاتيكي. 